\title{
SP140 Gene
}

National Cancer Institute

\section{Source}

National Cancer Institute. SP140 Gene. NCI Thesaurus. Code C150321.

This gene may play a role in transcriptional activation in leukocytes. 